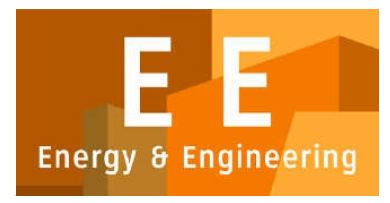

PAPER - OPEN ACCESS

\title{
Kearifan Lokal, Fasilitas Ruang Terbuka Hijau dan Fasilitas Nelayan di Desa Nelayan Pantai Bahari
}

\author{
Author \\ : Nurul Nadjmi \\ DOI \\ : 10.32734/ee.v2i1.383 \\ Electronic ISSN \\ : 2654-704X \\ Print ISSN \\ : 2654-7031
}

Volume 2 Issue 1-2019 TALENTA Conference Series: Energy \& Engineering (EE)

\section{(). 0 (ब)}

This work is licensed under a Creative Commons Attribution-NoDerivatives 4.0 International License.

Published under licence by TALENTA Publisher, Universitas Sumatera Utara

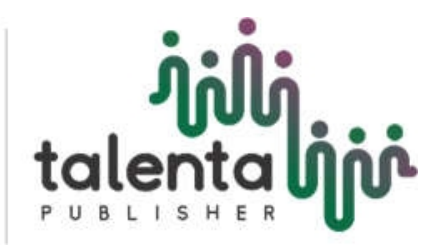




\title{
jibiti talentalioni TALENTA Conference Series
}

\section{Kearifan Lokal, Fasilitas Ruang Terbuka Hijau dan Fasilitas Nelayan di Desa Nelayan Pantai Bahari}

\author{
Nurul Nadjmi* \\ Departemen Arsitektur Fakultas Teknik Universitas Hasanuddin, Jl. Poros Malino KM. 6, \\ Bontomarannu Kabupaten Gowa, Sulawesi Selatan 92119, Indonesia \\ nurul_nadjmi@yahoo.com
}

\begin{abstract}
Abstrak
Pantai Bahari adalah salah satu kelurahan di Kecamatan Bangkala, Kabupaten Jeneponto, Sulawesi Selatan, Indonesia. Bangkala merupakan wilayah Kabupaten Jeneponto. Sedang kab. Jeneponto adalah salah satu kabupaten di Provinsi Sulawesi Selatan yang potensial untuk pengembangan rumput laut karena memiliki panjang pantai lebih dari $95 \mathrm{~km}$ dengan luas $749.79 \mathrm{~km} 2$. Salah satu jenis rumput laut yang dibudidayakan di Kabupaten Jeneponto adalah jenis Eucheuma Cottonii. Jenis ini mempunyai nilai ekonomis penting karena sebagai penghasil karajinan. Bangkala memiliki luas wilayah 121,82 km2, dengan jumlah penduduk sebesar 46.932 jiwa. Adapun kepadatannya adalah 385/km2. Tujuan penelitian ini adalah untuk mengetahui dan menganalisis secara mendalam mengenai fasilitas dan sarana hunian beserta penunjangnya yang terdapat di Desa Nelayan Pantai Bahari. Lingkup penelitian pada pembahasan ini adalah terfokus pada sarana hunian beserta fasilitas penunjang yang ada pada Kelurahan Pantai Bahari, Kecamatan Bangkala, Kabupaten Jeneponto Empati merupakan suatu proses memahami perasaan orang lain dan ikut merasakan yang orang lain rasakan. Metode penelitian yang digunakan dalam penelitian ini adalah penelitian deskriptif kualitatif. Penelitian ini dikondisikan sebagai penelitian kualitatif melalui strategi stui kasus. Sistem pendekatan yang digunakan juga merupakan pendekatan deskriptif analitik. Melakukan pengamatan langsung, mengumpulkan data-data kemudian menghubungkannya dengan kajian teori yang digunakan. Berdasarkan hasil survey yang saya lakukan di kecamatan Bangkala kabupaten Jeneponto menyatakan bahwa fasilitas-fasilitas yang terdapat disana secara keseluruhan kurang memadai, hal ini dikarenakan berdasarkan SNI belum terpenuhinya syarat-syarat maupun kriteria dalam membangun atau membuat suatu fasilitas masyarakat yang baik dan memadai.
\end{abstract}

Kata kunci: Kearifan Lokal; Fasilitas Ruang Terbuka Hijau; Fasilitas Nelayan; Pantai Bahari

\begin{abstract}
Pantai Bahari is one of the villages in Bangkala District, Jeneponto Regency, South Sulawesi, Indonesia. Bangkala is a region of Jeneponto Regency. Medium district. Jeneponto is one of the districts in South Sulawesi Province that has the potential to develop seaweed because it has a beach length of more than $95 \mathrm{~km}$ with an area of $749.79 \mathrm{~km} 2$. One type of seaweed that is cultivated in Jeneponto Regency is Eucheuma Cottonii. This type has important economic value because it is a producer of copy. Bangkala has an area of $121.82 \mathrm{~km} 2$, with a population of 46,932 people. The density is $385 / \mathrm{km} 2$. The purpose of this study was to find out and analyze in depth about residential facilities and facilities along with their support in the Bahari Beach Fisherman Village. The scope of the study in this discussion is focused on residential facilities and supporting facilities available at Pantai Bahari SubDistrict, Bangkala Sub-District, Jeneponto Regency Empathy is a process of understanding other people's feelings and participating in feeling what others feel. The research method used in this research is descriptive qualitative research. This research is conditioned as qualitative research through a strategy of case studies. The system approach used is also a descriptive analytic approach. They are conducting direct observations, collecting data and then connecting with the theoretical studies used. Based on the results of a survey that I conducted in Bangkala sub-district Jeneponto district stated that the facilities contained therein were inadequately inadequate, this was because SNI requirements and criteria had not been fulfilled in building a good and adequate community facility.
\end{abstract}

Keywords: Local Wisdom; Green Open Space Facilities; Fisherman Facilities; Bahari Beach 


\section{Pendahuluan}

Arsitektur tradisional merupakan salah satu bentuk kekayaan kebudayaan bangsa Indonesia. Keragaman arsitektur tradisional yang tersebar di bentang kawasan nusantara menjadi sumber ilmu pengetahuan yang tiada habis-habisnya. Arsitektur tradisional di setiap daerah menjadi lambang kekhasan budaya masyarakat setempat. Sebagai suatu bentuk kebudayaan, arsitektur tradisional dihasilkan dari satu aturan atau kesepakatan yang tetap dipegang dan dipelihara dari generasi ke generasi. Aturan tersebut akan tetap ditaati selama masih dianggap dapat memenuhi kebutuhan-kebutuhan masyarakat setempat.

Fasilitas merupakan segala sesuatu yang dapat memperlancar pekerjaan atau usaha untuk mencapai suatu tujuan. Dalam sebuah kawasan perumahan ataupun kawasan tempat tinggal diharuskan bahkan diwajibkan untuk memiliki suatu fasilitas agar masyarakat yang tinggal di area itu dapat dimudahkan dalam memenuhi segala kebutuhannya sehari-hari. Namun, beberapa daerah atau kawasan terkadang mempunyai fasilitas yang minim. Hal inilah yang dirasakan oleh masyarakat yang tinggal jauh dari pusat perkotaan dimana pusat perkotaan memiliki fasilitas yang sangat lengkap. Mereka membutuhkan suatu fasilitas agar segala keperluan sehari-hari mereka dapat terpenuhi, tidak perlu pergi jauh-jauh hingga ke pusat kota. Salah satunya adalah masyarakat di daerah pesisir yang jauh dari pusat kota. Untuk memenuhi kebutuhan dasar hidup sehari-hari, mereka memerlukan suatu fasilitas yang setiap unitnya mampu melayani masyarakat yang tinggal di daerah pesisir sesuai dengan Standar Nasional Indonesia (SNI) tentang fasilitas-fasilitas. Namun, pada kenyataannya beberapa kawasan tersebut tidak menggunakan SNI sebagai landasan mereka dalam membuat suatu unit fasilitas. Padahal seharusnya dalam membuat suatu unit fasilitas mereka sebaiknya menggunakan SNI agar fasilitas yang tersedia dapat benar-benar memadai bagi masyarakat setempat.

\section{Literatur}

\subsection{Arsitektur Tradisional Bugis-Makassar}

Arsitektur tradisional merupakan salah satu bentuk kekayaan kebudayaan bangsa Indonesia. Keragaman arsitektur tradisional yang tersebar di bentang kawasan nusantara menjadi sumber ilmu pengetahuan yang tiada habis-habisnya. Arsitektur tradisional di setiap daerah menjadi lambang kekhasan budaya masyarakat setempat. Sebagai suatu bentuk kebudayaan, arsitektur tradisional dihasilkan dari satu aturan atau kesepakatan yang tetap dipegang dan dipelihara dari generasi ke generasi. Aturan tersebut akan tetap ditaati selama masih dianggap dapat memenuhi kebutuhan-kebutuhan masyarakat setempat. Begitupun dengan kawasan di daerah kampung nelayan Pantai Bahari kecamatan Bangkala kabupaten Jeneponto. Walaupun kawasan ini merupakan kawasan pesisir karena permukimannya yang berjejer di sepanjang pinggir pantai, ciri khas arsitekturnya juga tidak beda jauh dengan konsep arsitektur tradisional bugis. Konsep arsitektur masyarakat tradisional Bugis-Makassar bermula dari suatu pandangan hidup ontologis, bagaimana memahami alam semesta secara "universal". Filosofi hidup masyarakat tradisional Bugis Makassar yang disebut "Sulapa Appa", menunjukkan upaya untuk "menyempurnakan diri". Filosofi ini menyatakan bahwa segala aspek kehidupan manusia barulah sempurna jika berbentuk "Segi Empat". Filosofi yang bersumber dari "mitos" asal mula kejadian manusia yang diyakini terdiri dari empat unsur, yaitu : tanah, air, api, dan angin. Selain itu, Nilai Falsafah pada pandangan kosmologis suku bangsa Bugis menganggap bahwa makro-kosmos (alam raya) ini bersusun tiga tingkat yaitu : Botting Langi' (dunia atas), Ale kawa (dunia tengah), Uri liyu' (dunia bawah). Sebagai pusat dari ketiga bahagian alam raya ini ialah Botting Langi' (langit tertinggi) tempat Dewata Seuwae (Tuhan Yang Maha Esa) bersemayam. Pandangan ini diwujudkan dalam bangunan rumah yang dipandang sebagai mikrokosmos. Oleh karena itulah tempat tinggal orang bugis dibagi menjadi atas tiga tingkat, yaitu :

- $\quad$ Rakkeang (rakkiang, loteng)

- Ale Bola (badan rumah) yaitu lantai tempat tinggal)

- Awa Bola (kolong rumah)

\subsection{Letak dan Arah Rumah}

Arah rumah senantiasa mengikuti empat penjuru angin, yaitu timur, barat, selatan . kaidah-kaidah adat nampaknya masih diikuti oleh orang bugis dimana saja berada. Pertama-tama jika seorang bugis yang ingin rumah baru memiliki pandangan. Pada seorang Parita-bola atau urangi-bolaarah ana sebaiknya rumah dihadapkan, maka melalui urangibola tersebut nentuan titik mana ditempat itu diletakkan pusar rumah. Seorang panrita-bola mungkin saja memperhitungkan faktor-faktor ekonomis dan strategis, tetapi faktor kaidah-kaidah adat masih tetap diperhatikan. 
Letak rumah adalah paling ideal bila di bangun dekat anggota keluarga baik keluarga suami atau keluarga istri maupun dekat famili-famili. Perhitungan kedua, memilih tanah yang rata, kalau tidak dipilih tanah yang tinggi kalau tidak dipilih tanah yang tinggi sebelah barat atau tinggi sebelah selatan.

Sehubungan dengan arah rumah, satu hal yang jarang tampak pada tiap-tiap rumah ialah tamping ( ruang tambahan samping). Adanya ruang tamping idak berdasar norma sebalah kiri atau kanan, akan tetapi lebih banyak dihubungkan dengan arah rumah. Apabila rumah menghadap utara, maka tamping diletakkan sebelah timur dan apabila menghadap ebarat, maka tamping diletakkan disebalah barat. Hal ini mungkin di hubungkan dengan perletakan kepala waktu tidur, di pandang baik jika tidur kepala terletak disebelah barat. Pandangan mengenai arah ini turut mempengaruhi susunan dan letak perabot rumah tangga, termasuk letak tempat tidur dan dapur.

\subsection{Ruang Terbuka Hijau}

Dampak kerusakan lingkungan yang dirasakan akibat aktivitas manusia ataupun bencana alam dapat dikurangi dengan pengembangan Ruang Terbuka Hijau (RTH) yang memenuhi kriteria-kriteria yang telah ditetapkan. Beberapa vegetasi pohon yang tumbuh di kawasan sempadan Pantai Bahari Jeneponto telah mengalami kerusakan atau tidak dapat tumbuh secara ideal.

Kerusakan yang dialami oleh tanaman-tanaman hijau ini disebabkan oleh upaya pengelolaan yang kurang intensif dan optimal, sehingga fungsi ruang hijau di Pantai Bahari Jeneponto tidak tersedia secara ideal. Upaya penghijauan yang dapat berfungsi sebagai pemecah ombak dan pengembangan ruang hijau merupakan langkah utama dalam upaya pencegahan dampak abrasi pantai. Penanaman jalur hijau di sepanjang sempadan pantai juga merupakan pemecahan dari masalah pencemaran pantai akibat limbah industri dan rumah tangga, memberikan fungsi perlindungan, ekologi dan ekonomi serta meningkatkan daya tarik pantai sebagai keunggulan pariwisata.

\subsection{Fasilitas Nelayan}

\subsubsection{Pangkalan Pendaratan Ikan}

Pangkalan Pendaratan Ikan merupakan salah satu unsur prasarana ekonomi yang dibangun dengan maksud untuk menunjang tercapainya pembangunan perikanan terutama perikanan skala kecil. Sebagai prasarana pelayanan umum (public utilities), fungsi PPI dapat dikelompokkan menjadi [1]:

- Prasarana untuk memperlancar kegiatan produksi kapal perikanan, pengelolaan dan pemasaran hasil perikanan serta pelayanan keperluan logistik.

- Sebagai pusat pengembangan masyarakat nelayan seperti pembinaan dan penyuluhan cara-cara melakukan produksi yang baik.

- Sebagai pusat pembangunan ekonomi perikanan setempat melalui pengembangan industri perikanan.

Lubis menyatakan bahwa pada umumnya PPI ditujukan untuk berlabuh atau bertambatnya perahu-perahu penangkapan ikan tradisional yang berukuran lebih kecil dari 5 GT atau untuk perahu perahu layar tanpa motor. Hasil tangkapan yang didaratkan lebih kecil dari 20 ton/hari dan ditujukan terutama untuk pemasaran lokal.

\subsubsection{Tempat Penyimpanan dan Pengawetan Ikan}

Ikan merupakan makanan yang mudah mengalami pembusukan. Apalagi di daerah tropis seperti Indonesia yang bersuhu relatif tinggi. Akan tetapi, umur penyimpanan ikan dapat diperpanjang dengan penurunan suhu. Bahkan ikan yang dibekukan dapat disimpan sampai beberapa bulan, sampai saat dibutuhkan ikan dapat dilelehkan dan diolah lebih lanjut oleh konsumen. Rantai aliran makanan beku atau rantai dingin (cold chain) umumnya terdiri dari: pembekuan, penyimpanan dalam gudang dingin, diangkut dengan mobil berpendingin (refrigerated truck), dipamerkan dalam lemari dingin di toko makanan, akhirnya disimpan di dalam freezer lemari es di rumah. Pembekuan ikan berarti menyiapkan ikan untuk disimpan di dalam suhu rendah cold storage. Seperti pendinginan, pembekuan dimaksudkan untuk mengawetkan sifat-sifat alami ikan, Pembekuan menggunakan suhu yang lebih rendah, yaitu jauh di bawah titik beku ikan, Pembekuan mengubah hampir seluruh kandungan air pada ikan menjadi es, tetapi pada waktu ikan beku dilelehkan kembali untuk digunakan, keadaan ikan harus kembali seperti sebelum dibekukan. 


\subsubsection{Tempat Pengeringan Ikan}

Pengeringan merupakan cara pengawetan ikan dengan mengurangi kadar air pada tubuh ikan sebanyak mungkin. Tubuh ikan mengandung 56-80\% air, jika kandungan air ini dikurangi, maka metabolisme bakteri terganggu dan akhirnya mati. Pada kadar air $40 \%$ bakteri sudah tidak dapat aktif, bahkan sebagian mati, namun sporanya masih tetap hidup. Spora ini akan tumbuh dan aktif kembali jika kadar air meningkat. Oleh karena itu, ikan hampir selalu digarami sebelum dilakukan pengeringan.

Kecepatan pengeringan ditentukan oleh faktor-faktor sebagai berikut:

- Kecepatan udara, makin cepat udara di atas ikan, makin cepat ikan menjadi kering.

- Suhu udara, makin tinggi suhu, makin cepat ikan menjadi kering

- Kelembaban udara, makin lembab udara, makin lambat ikan menjadi kering

- Ukuran dan tebal ikan, makin tebal ikan, makin lambat kering.

- Makin luas permukaan ikan, makin cepat ikan menjadi kering.

- Arah aliran udara terhadap ikan, makin kecil sudutnya, makin cepat ikan menjadi kering.

- Sifat ikan, ikan berlemak lebih sulit dikeringkan

Cara pengeringan terbagi dua golongan yaitu pengeringan alami dan buatan. Pada pengeringan alami, ikan dijemur di atas rak-rak yang dipasang agak miring $\left(+15^{\circ}\right)$ ke arah datangnya angin, dan diletakkan di bawah sinar matahari tempat angin bebas bertiup. Lamanya penjemuran 8 jam/hari selama 3 hari di daerah dengan intensitas sinar matahari tinggi. Pekerjaan penjemuran harus disertai pembalikkan 2-3 kali setiap hari. Untuk mengukur tingkat kekeringan ikan, dengan cara menekan tubuh ikan menggunakan ibu jari dan telunjuk tangan. Pada ikan kering tekanan jari tidak akan menimbulkan bekas. Cara lain dengan melipat tubuh ikan. Ikan kering tidak akan patah jika tubuhnya dilipatkan.

\subsubsection{Bangunan Pemecah Gelombang}

Pemecah gelombang atau dikenal sebagai juga sebagai Pemecah ombak atau bahasa Inggris breakwater adalah prasanana yang dibangun untuk memecahkan ombak atau gelombang, dengan menyerap sebagian energi gelombang. Pemecah gelombang digunakan untuk mengendalikan abrasi yang menggerus garis pantai dan untuk menenangkan gelombang dipelabuhan sehingga kapal dapat merapat dipelabuhan dengan lebih mudah dan cepat.

Pemecah gelombang harus didesain sedemikian sehingga arus laut tidak menyebabkan pendangkalan karena pasir yang ikut dalam arus mengendap di kolam pelabuhan. Bila hal ini terjadi maka pelabuhan perlu dikeruk secara reguler.

Ada beberapa cara yang dapat dilakukan untuk melindungi pantai, yaitu:

- Memperkuat/melindungi pantai agar mampu menahan serangan gelombang,

- Mengubah laju transpor sedimen sepanjang pantai,

- Mengurangi energi gelombang yang sampai ke pantai,

- Reklamasi dengan manambah suplai sedimen ke pantai atau dengan cara lain.

\subsubsection{Kawasan Wisata Pantai}

Sumberdaya kelautan dengan aneka-ragam ekosistemnya yang berupa keaneka- ragaman flora, fauna dan gejala alam dengan keindahan pemandangan alamnya merupakan anugerah Tuhan Yang Maha Esa. Potensi sumberdaya alam bahari dan ekosistemnya ini dapat dikembangkan dan dimanfaatkan sebesar-besarnya bagi kesejahtraan rakyat dengan tetap memperhatikan upaya konservasi dan rehabilitasinya. Sumberdaya alam yang dapat dimanfaatkan sebagai pelestarian alam dan sekaligus sebagai obyek wisata alam, adalah: taman laut, pesisir-pantai, flora termasuk hutan, fauna, dan berbagai bentuk ekosistem khusus.

Pengertian wisata alam meliputi obyek dan kegiatan yang berkaitan dengan rekreasi dan pariwisata yang memanfaatkan potensi sumberdaya alam dan ekosistemnya, baik dalam bentuk asli (alami) maupun perpaduan dengan hasil karya atau buatan manusia. Manusia sudah mulai jenuh dengan kehidupan perkotaan yang sibuk oleh berbagai kegiatan industri dan bisingnya kota. Akibatnya tempat-tempat rekreasi di alam terbuka yang sifatnya masih alami dan dapat memberikan kenyamanan semakin banyak dikunjungi orang (wisatawan). 


\subsubsection{Budidaya Rumput Laut}

Rumput laut merupakan golongan tumbuhan perairan di laut yang berukuran besar, dapat dilihat dengan mata biasa tanpa alat pembesar dan disebut juga makroalga. Secara alami rumput laut bersifat bentik atau tumbuh menancap atau menempel pada suatu substrat di perairan laut. Jenis rumput laut yang tumbuh di laut diperkirakan ada ribuan jenis. Produksi rumput laut di Indonesia berasal dari hasil budidaya di laut dan tambak maupun hasil pengambilan dari alam. Jumlah produksi rumput laut yang berasal dari alam semakin menurun dan digantikan dari Jenis rumput laut yang dibudidayakan di laut terdiri dari Kappaphycus alvarezii (sebelumnya dikenal dengan nama Eucheuma cottonii), Kappaphycus striatum dan Eucheuma denticulatum. Kappaphycus alvarezii dan Kappaphycus striatum dalam dunia perdagangan dikenal dengan nama Kotoni, sedangkan Eucheuma denticulatum memiliki nama dagang Spinosum.

Berdasarkan produksi global rumput laut yang dilaporkan oleh FAO pada tahun 2010, Indonesia merupakan negara produsen terbesar untuk Kotoni (63,37\% dari total produksi dunia) dan menempati urutan kedua untuk Gracilaria (30,02\% dari produksi total dunia). Secara nasional, produksi rumput laut di Indonesia juga didominasi oleh Kotoni dan Gracilaria. Usaha budidaya rumput laut di laut banyak dilakukan oleh masyarakat pesisir di Indonesia, dijadikan sebagai pekerjaan utama maupun sampingan. Beberapa keuntungan dalam budidaya rumput laut adalah: 1) Tidak memelukan modal yang tinggi, 2) Teknologi budidaya yang diterapkan adalah teknologi sederhana sehingga mudah diadopsi oleh masyarakat kecil, 3) Efisien dalam pemanfaatan waktu, 4) Siklus budidaya singkat, pembudidaya bisa mendapatkan hasil panen dalam waktu 45 hari, 5) Budidaya rumput laut dapat dilakukan oleh siapa saja termasuk para ibu rumah tangga.

\section{Metode Penelitian}

Metode penelitian yang digunakan dalam penelitian ini adalah penelitian deskriptif kualitatif. Penelitian ini dikondisikan sebagai penelitian kualitatif melalui strategi stui kasus. Sistem pendekatan yang digunakan juga merupakan pendekatan deskriptif analitik. Melakukan pengamatan langsung, mengumpulkan data-data kemudian menghubungkannya dengan kajian teori yang digunakan.

\section{Hasil dan Analisis}

\subsection{Eksisting Condition}

Pantai Bahari adalah salah satu kelurahan di Kecamatan Bangkala, Kabupaten Jeneponto, Sulawesi Selatan, Indonesia. Bangkala merupakan wilayah Kabupaten Jeneponto. Sedang kab. Jeneponto adalah salah satu kabupaten di Provinsi Sulawesi Selatan yang potensial untuk pengembangan rumput laut karena memiliki panjang pantai lebih dari $95 \mathrm{~km}$ dengan luas $749.79 \mathrm{~km} 2$. Salah satu jenis rumput laut yang dibudidayakan di Kabupaten Jeneponto adalah jenis Eucheuma Cottonii. Jenis ini mempunyai nilai ekonomis penting karena sebagai penghasil karajinan. Bangkala memiliki luas wilayah 121,82 km2, dengan jumlah penduduk sebesar 46.932 jiwa. Adapun kepadatannya adalah $385 / \mathrm{km} 2$ (gambar 1). 


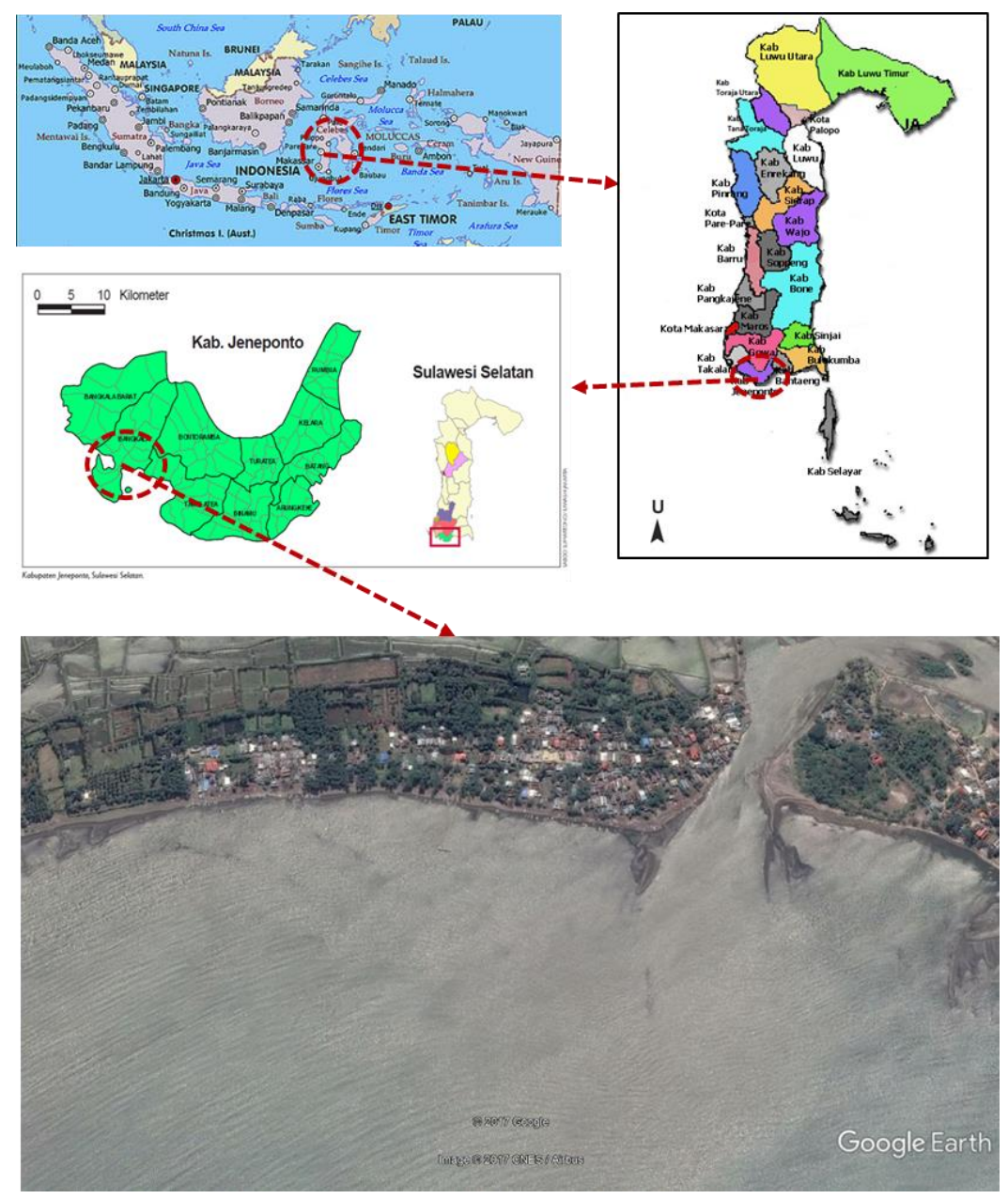

Gambar 1. Lokasi Desa Nelayan Pantai Bahari, Kec. Bangkala, Jeneponto. Provinsi Sulawesi Selatan. Sumber: http//www.GoogleEarth.Com (diakses tanggal 07-04-2017)

\subsection{Ruang Terbuka Hijau}

Ruang terbuka hijau pada kawasan pemukiman pesisir Pantai Bahari, Jeneponto belum tertata dengan baik. Hanya ada beberapa bale-bale yang tersebar di sepanjang bahu jalan pemukiman yang menjadi tempat berkumpul masyarakat (gambar 2).

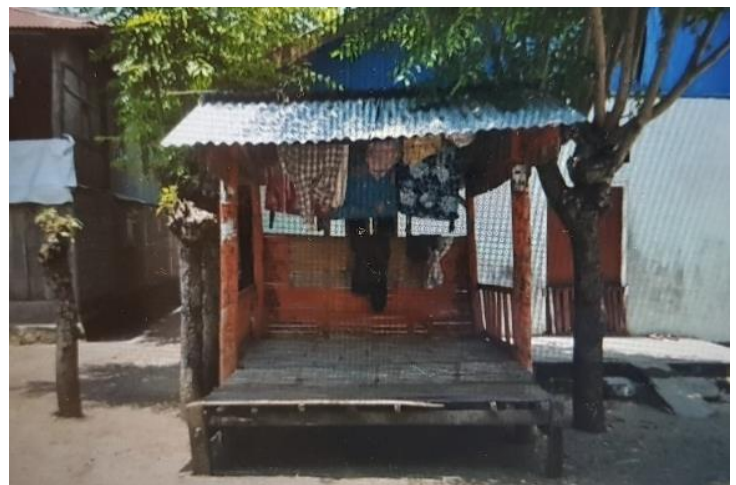

Gambar 2. Salah Satu Bale-bale yang berada di Permukiman Nelayan Pantai Bahari Sumber : dokumentasi pribadi

Ruang terbuka yang lain difungsikan masyarakat sebagai tempat perakitan dan penjemuran jaring rumput laut. Pengolahan kawasan terpadu rumput laut belum ditata dengan baik (gambar 3). 


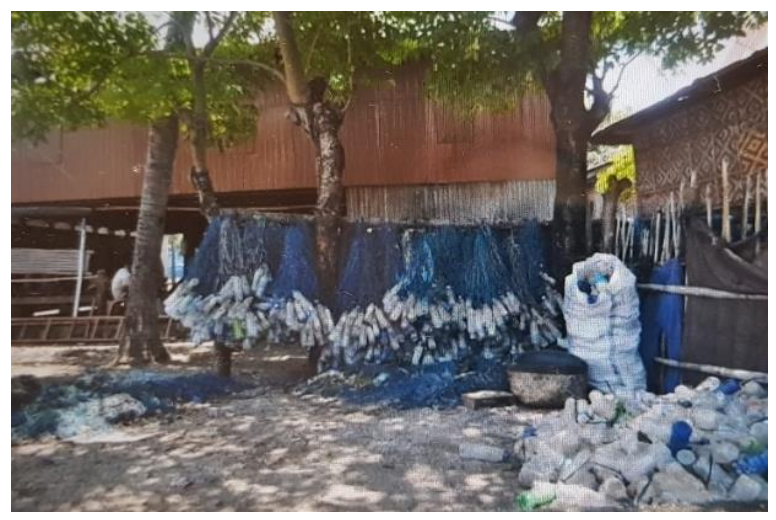

Gambar 3. Ruang Terbuka yang di alih fungsikan Sumber : dokumentasi pribadi

Ketidakseimbangan perkembangan ruang terbangun dan ruang terbuka publik (khususnya yang berupa ruang terbuka hijau) ini tentu tidak baik, baik dari sisi lingkungan maupun kepariwisataan. Dari sisi lingkungan, sedikitnya ruang terbuka hijau berarti semakin sedikit pula air yang terserap oleh tanah. Suasana menjadi panas (karena tidak ada pepohonan peneduh dan penyerap karbondioksida) dan supply oksigen sedikit. Semua ini berujung pada berkurangnya kenyamanan pada objek wisata. Harus dilakukan upaya penyeimbang perkembangan ruang terbangun, yaitu dengan menciptakan ruang terbuka publik, khususnya yang berupa ruang terbuka hijau (gambar 4-5).
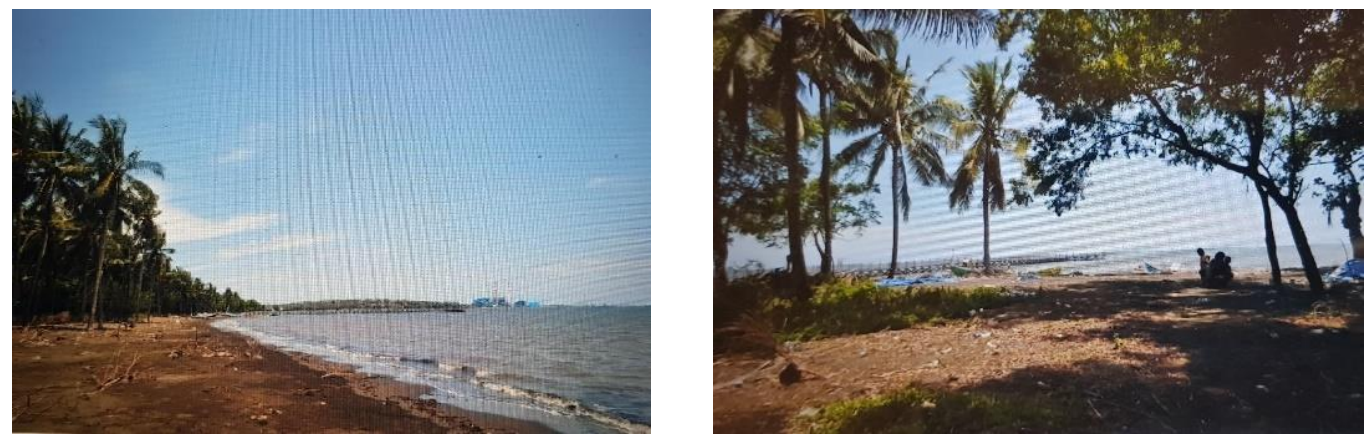

Gambar 4. Salah Satu Ruang Terbuka Hijau yang Terdapat di Permukiman Nelayan Pantai Bahari Sumber : dokumentasi pribadi

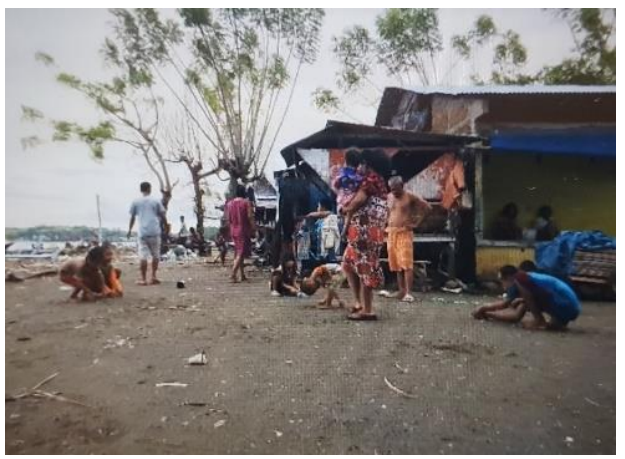

Gambar 5. Pemanfaatan RTH yang berada di sepanjang pesisir pantai difungsikan masyarakat sebagai lahan bermain anak Sumber : dokumentasi pribadi

Lahan di sekitar kawasan wisata Pantai Bahari masih didominasi oleh lahan terbuka berupa tegalan, dengan topografi datar - landai dan tekstur material tanahnya berpasir. Dengan demikian, tidak terdapat hambatan pengerjaan konstruksi. Beberapa warga memfungsikan tegalan tersebut sebagai lahan menjemur rumput laut dan jaringnya, 
namun sebagian besar tegalan tidak difungsikan secara khusus oleh masyarakat setempat (dibiarkan begitu saja dan ditumbuhi alang-alang,).

Masih luasnya lahan tidur yang ada di sekitar kawasan wisata Pantai Bahari ini merupakan suatu potensi. Sebelum lahan tidur tersebut dijadikan ruang terbangun, hendaknya terdapat alokasi ruang untuk ruang terbuka publik khususnya ruang terbuka yang berupa ruang terbuka hijau. Pada lokasi tapak telah tumbuh beberapa pepohonan. Hal ini merupakan modal tersendiri bagi pembentukan ruang terbuka hijau. Pepohonan yang telah ada tidak perlu ditebang, hanya perlu ditata dan dirapikan. Dengan demikian, pengembangan ruang terbuka hijau ini mengedepankan pemanfaatan potensi dan sumberdaya lokal

Tapak yang akan dikembangkan di lingkungan masyarakat tentunya akan memberikan dampak. Kemungkinan dampaknya bisa saja baik ataupun malah buruk. Namun dalam hal ini, setelah dilakukan kajian lebih mendalam terhadap lingkungan sekitar lokasi tapak, pada kenyataanya banyak sekali dampak positif yang akan dirasakan khususnya oleh masyarakat. Sedikitnya ada empat dampak yang akan dirasakan oleh masyarakat, antara lain yaitu:

$\square$ memotivasi masyarakat agar ikut melestarikan lingkungan dengan cara menata ruang hijau di sekitar tempat tinggal mereka $\square$ menjadi sarana hiburan alternatif wisatawan di Pantai Bahari, $\square$ menambah pendapatan objek wisata Jenepontoepok dengan adanya sarana daya tarik wisatawan Pantai Bahari, dan $\square$ menjadi sarana hiburan masyarakat sekitar karena adanya lapangan olahraga dan ruang terbuka hijau yang ideal.

Keberadaan tapak yang akan dibuat tentunya akan berpengaruh pada lingkungan sekitar. Jika pada kenyataanya terdapat dampak negatif yang ditimbulkan, maka tentunya dampak tersebut tidak ingin dirasakan oleh lingkungan maupun masyarakat sekitar sehingga secara tidak langsung hal tersebut berimplikasi pada pembatalan terbentuknya tapak. Namun, dari sudut pandang yang lain justru hal tersebut dapat terlihat berbeda. Jika dilihat dari sudut pandang positif yaitu berdampak positif terhadap lingkungan, maka setidaknya ada empat dampak yang akan ditimbulkan diantaranya (gambar 6) yaitu:

- Melindungi pantai dari bahaya abrasi

- Mengurangi efek pemanasan matahari di waktu siang hari

- Menghijaukan pantai

- Terjaganya kelestarian jenis tanaman pantai, dan

- Mengurangi kecepatan air laut sampai di darat
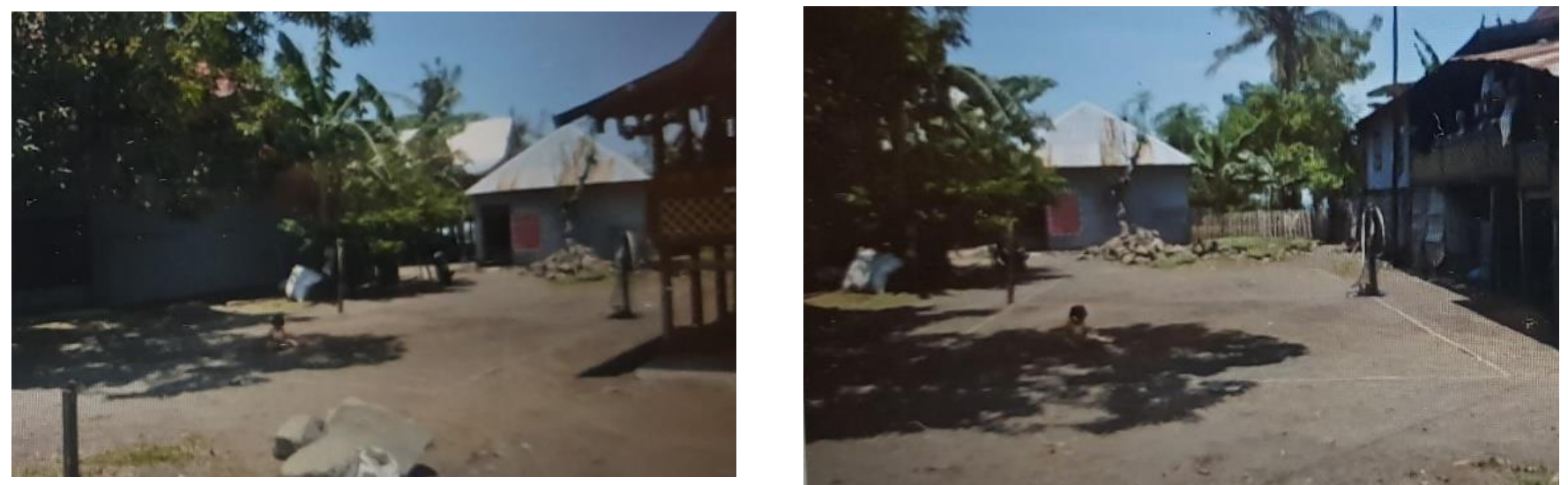

Gambar 6. Lapangan di Permukiman Pesisir Pantai Bahari, Jeneponto

Sumber : dokumentasi pribadi 


\subsection{Fasilitas Nelayan}

\subsubsection{Dermaga}

Dermaga yang terdapat pada permukiman nelayan Pantai Bahari (gambar 7) :
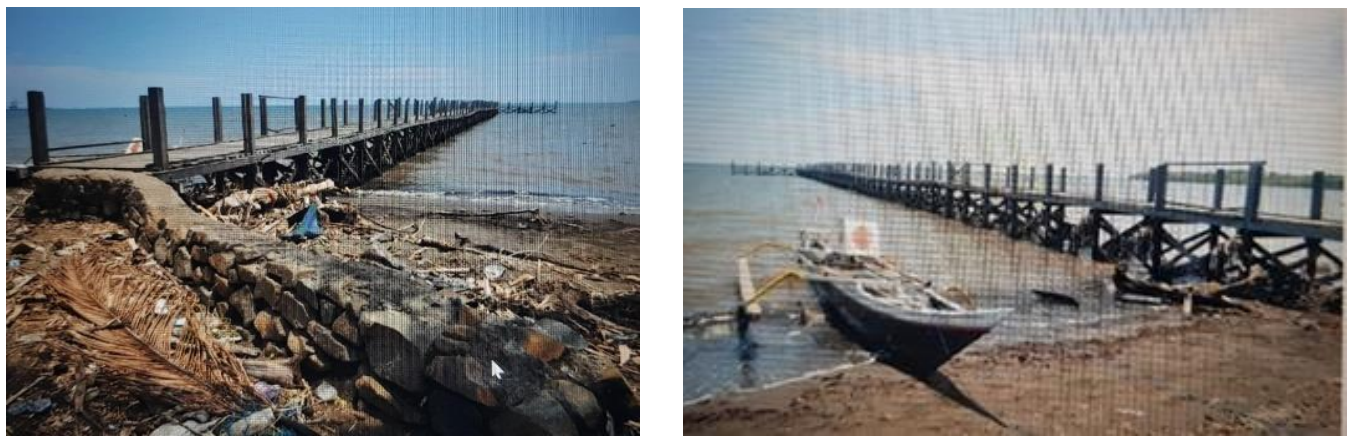

Gambar 7. Dermaga yang Terdapat di Permukiman Nelayan Pantai Bahari, Jeneponto Sumber : dokumentasi pribadi

\subsubsection{Tempat penambatan perahu}

Perahu nelayan ikan tangkap Pantai Bahari, Jeneponto ditambatkan di sepanjang bibir pantai bagian arah utara pantai sebagai kawasan penangkapan ikan. Pada kawasan bagian selatan digunakan para nelayan rumput laut. Kawasan selatan pantai hanya memiliki sedikit ikan karena menurut masyarakat setempat diakibatkan oleh adanya pembangunan Pembangkit Listrik Tenaga Uap di seberang pantai sehingga tidak bbanyak ikan di wilayah selatan (gambar 8).
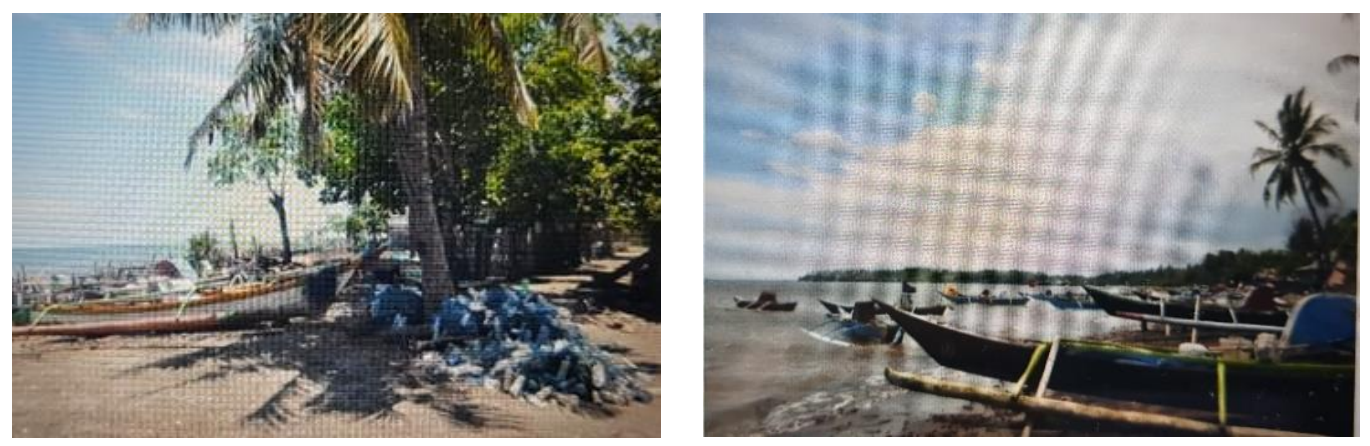

Gambar 8. Tempat Penambatan Perahu yang Terdapat di Permukiman Nelayan Pantai Bahari, Jeneponto Sumber : dokumentasi pribadi

\subsubsection{Tempat Pengumpulan Ikan}

Ikan-ikan hasil tangkapan nelayan Pantai Bahari kemudian ditimbang lalu langsung dibawa ke pasar untuk dijual. Tidak terdapat tempat Pelelangan ikan ataupun Pangkalan Pendaratan Ikan yang memberikan pelayanan umum dan jasa untuk memperlancar kegiatan perahu atau kapal perikanan dan usaha perikanan (gambar 9). 


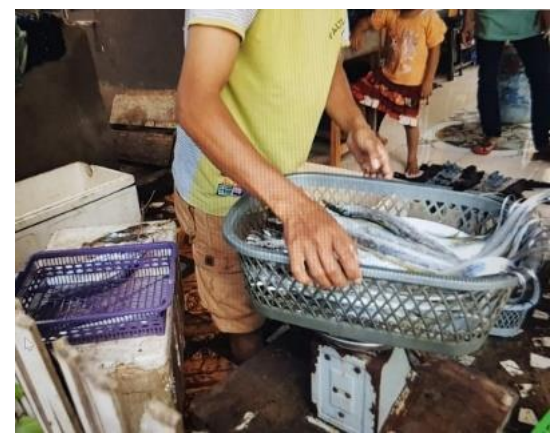

Gambar 9. Tempat Pengumpulan Ikan yang Terdapat di Permukiman Nelayan Pantai Bahari, Jeneponto Sumber : dokumentasi pribadi

\subsubsection{Tempat Penjemuran Ikan}

Sebagian nelayan menjemur ikan hasil tangkapannya di dermaga dan kolong-kolong rumah. Tidak terdapat wilayah khusus penjemuran ikan yang memudahkan nelayan mengelola dan memaksimalkan hasil tangkapannya. Hasil tangkapan Ikan di Pantai Bahari disimpan dalam kotak kecil yang setelah ditimbang dibawa langsung ke pasar. Adapun hasil tangkapan ikan yang tidak ditimbang, dijemur di kolong-kolong rumah nelayan. (gambar 10) :
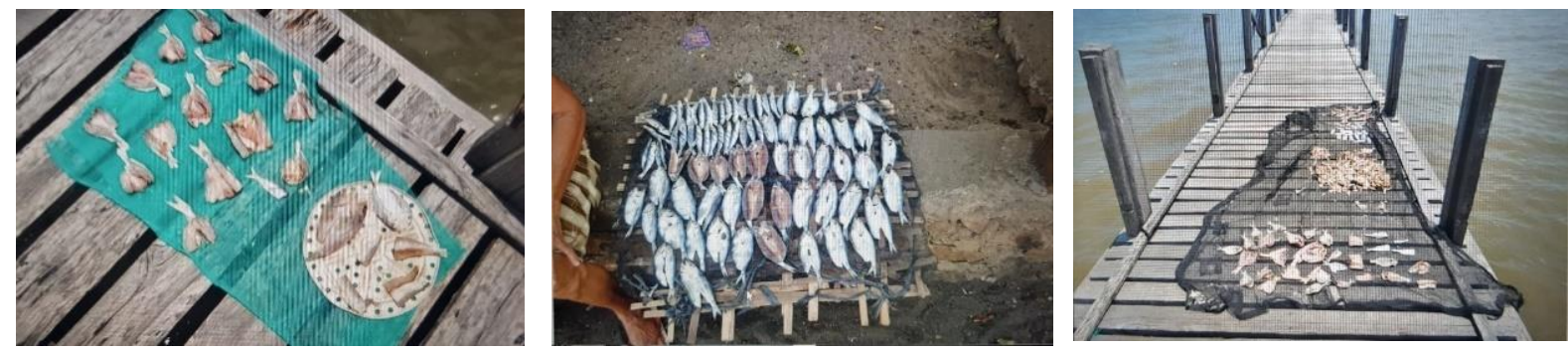

Gambar 10. Tempat Penjemuran Ikan yang Terdapat di Permukiman Nelayan Pantai Bahari, Jeneponto Sumber : dokumentasi pribadi

\subsection{Tempat Pengumpulan Rumput Laut}

Hanya ada dua jenis rumput laut yang terdapat di Pantai Bahari, Jeneponto:

- Kappaphycus alvarezii (Alga Merah), Sebelumnya disebut Eucheuma cottonii. Nama lokal: Katoni, Tambalang, Rumput Laut Kangkung Katoni

- Eucheuma denticulatum sebelumnya disebut Eucheuma spinosum. Nama Lokal: Spinosum, Safari Turbinaria conoides, (Alga Cokelat)

Beberapa masyarakat menjemur hasil tangkapan rumput lautnya di halaman rumah dan sepanjang bibir pantai bagian selatan (gambar 11).
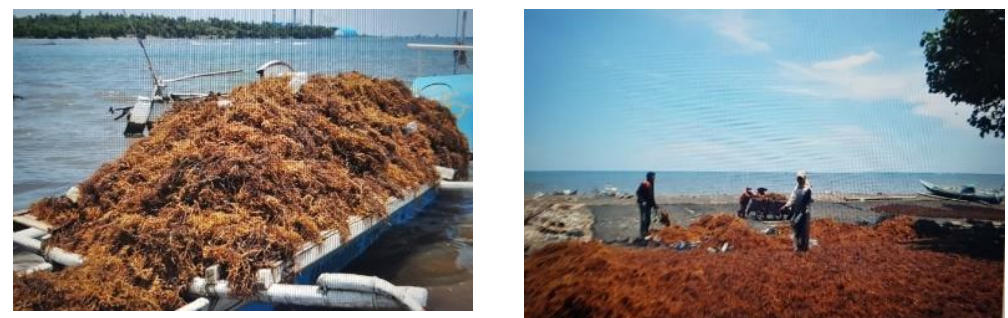

Gambar 11. Tempat Pengumpulan Rumput Laut yang Terdapat di Permukiman Nelayan Pantai Bahari, Jeneponto Sumber : dokumentasi pribadi 


\subsubsection{Masalah}

Permasalahan pada permukiman Nelayan Pantai Bahari,yaitu (gambar 12) :

- Sampah Sampah-sampah organik dan anorganik serta bangkai-bangkai batang pohon kering berserakan di sepanjang pantai.

- Drainase Masih kurang memadainya jaringan drainase di pemukiman pesisir Pantai Bahari, Jeneponto sehingga menimbulkan beberapa titik daerah yang dipenuhi genangan-genangan air buangan rumah tangga.
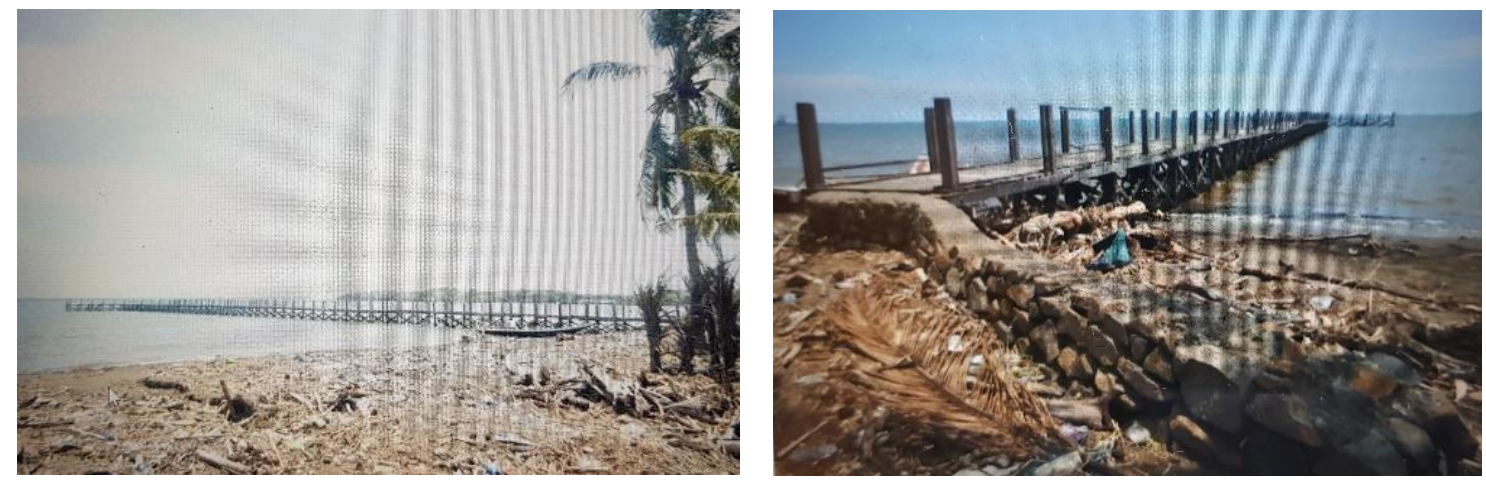

Gambar 12. Tempat Pengumpulan Rumput Laut yang Terdapat di Permukiman Nelayan Pantai Bahari, Jeneponto Sumber : dokumentasi pribadi

\subsubsection{Output}

Berdasarkan permasalahan yang telah dikemukakan di atas, maka ada beberapa hasil analisis, sebagai berikut:

- Perlunya pemanfaatan RTH yang baik dan kreatif sehingga lebih banyak tanah kosong yang dimanfaatkan oleh masyarakat sebagai ruang public tempat berkumpul dan menjadi wisata yang menarik bagi pengunjung Pantai Bahari, Jeneponto

- Perlunya dibangun Pangkalan Pendaratan Ikan (PPI) yang memudahkan nelayan memperlancar kegiatan perahu atau kapal perikanan dan usaha perikanan serta sebagai pusat pengembangan masyarakat nelayan seperti pembinaan dan penyuluhan cara-cara melakukan produksi yang baik.

Adapun fasilitas-fasilitas yang dibutuhkan, meliputi:

- Tempat Pelelangan Ikan (TPI)

- Tangki BBM dan instalasinya

- Tangki air tawar dan instalansinya

- Instalasi listrik

- Cold storage

- Dock atau slipway

- Bengkel

- Tempat penanganan pengolahan

- Tempat penjemuran ikan

- Tempat penjemuran atau perbaikan jaring

Perlunya dibangun bangunan pemecah gelombang jenis krib yang berupa susunan silinder dari beton yang bisa menjadi bangunan yang eksotis dan diatasnya bisa menjadi tempat berdiri sambil memandang lepas ke arah laut. Perlu adanya kawasan budidaya rumput laut sehingga memudahkan nelayan dalam mengelola hasil tangkapannya (gambar 13). 


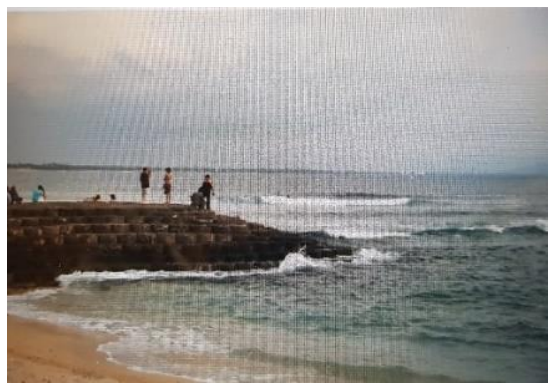

Gambar 13. Pemecah Ombak yang dapat di gunakan pada Permukiman Pantai Bahari Sumber : dokumentasi pribadi

\section{Kesimpulan dan Saran}

\subsection{Kesimpulan}

Kesimpulan Arsitektur bangunan Tradisional yang berada di permukiman pesisir Kelurahan Pantai Bahari, Jeneponto menganut pandangan arsitektur suku bangsa bugis-makassar yakni budaya Sulawesi Selatan, yang dimana mengandung nilai-nilai budaya falsafah dan nilai status sosial. Rumah tradisional masyarakat Bugis Makassar terkenal dengan bentuk panggung, hal tersebut telah menjadi ciri tersendiri dalam budaya Bugis Makassar. Demikian pula dengan rumah tradisional masyarakat di kampung nelayan Pantai Bahari Kecamatan Bangkala Kabupaten Jeneponto. Pada umumnya rumah yang ada di daerah tersebut memiliki ciri khas rumah Bugis Makassar, yang mana terdiri dari filosofi dunia bawah, dunia tengah, dan dunia atas.

\subsection{Saran}

Untuk pembelajaran maka penulis memberikan saran yaitu, perlunya penambahan sumber-sumber buku yang jauh lebih akurat lagi agar mahasiswa dapat mempelajari jauh lebih dalam mengenai arsitektur tradisional Sulawesi Selatan khusunya permukiman pesisir Kabupaten Jeneponto dan untuk mengoptimalkan pemahaman mahasiswa mengenai arsitektur tradisional Sulawesi Selatan diperlukan materi-materi yang mudah dipahami dan pembimbing yang bisa memantau para mahasiswa dalam pembelajaran

\section{Referensi}

[1] DKP. 2003. "Budidaya Rumput Laut dengan Metode Lepas Dasar Sebagai Pekerjaan Sambilan Nelayan yang Menguntungkan”. Sulawesi Selatan.

[2] Noor, Z., 1990. “Sistem Tanam dan Kualitas Rumput Laut”. Yogyakarta : Buku Panduan dan kumpulan Abstrak Seminar Ilmiah Nasional Lustrum VII.

[3] Putinella, J.D. 2001. "Evaluasi lingkungan budidaya rumput laut di teluk bagula". Yogyakarta : Usulan Penelitian Program Pascasarjana Universitas Gajah Mada.

[4] Simanjuntak, P., 1995. "Senyawa Bioaktif dari Alga Hayati”. Bogor : Penerbit Jurusan Biologi FMMIPA IPB.

[5] Sulitijo, 1985. "Budidaya Rumput Laut”. Bandar Lampung : Seafarming workshop. 